\title{
PECULIARITIES OF LEARNING ACTIVITIES OF STUDENTS WITH INTELLECTUAL DISABILITIES
}

Nazira Yusupova

Senior Lecturer Tashkent State Pedagogical University Tashkent, Uzbekistan

\section{ABSTRACT}

The article is devoted to the study of the features of the educational activity of students with intellectual disabilities.

KEYWORDS:- Dynamics of activity, educational motivation, motivation-need sphere, social motives.

\section{INTRODUCTION}

A mentally retarded student does not act in accordance with a set goal (when performing a difficult task), but is guided by his own, peculiarly conscious task. When completing the assignment on his own, he does not take into account all the data and requirements. As a result, the task is replaced by another, similar, but less complex one. In the process of activity, mentally retarded children not only perceive the surrounding reality in a peculiar way, think and remember, but are also guided by other motives and goals than their normal peers.

In the activity of a mentally retarded student, the features of his personality are manifested. The goals and motives by which he is guided in the process of activity, the dynamics of activity - all this reflects the characteristic features of his personality.

\section{THE MAIN RESULTS AND FINDINGS}

The creation of conditions for the development and formation of motives during the period of study in elementary school, giving the child's further educational activities a meaningful meaning for him, is extremely necessary. Lack of educational motivation is an indicator of the child's non-involvement in the educational process. To organize constructive work on the formation and development of educational motivation in a younger student with developmental problems, it is important for a teacher to know:

- General trends in the age-related development of a student;

- Individual characteristics of the student;

The motivational sphere of a mentally retarded child, as in the norm, is formed in activity. The 
CURRENT RESEARCH JOURNAL OF PEDAGOGICS 2(11): 138-142,

November 2021 DOI: https://doi.org/10.37547/pedagogics-crjp-02-11-26

ISSN 2767-3278

(C)2021 Master Journals

Crossref do: 81 Google

Accepted 25th November, 2021 \& Published 30 ${ }^{\text {th }}$ November, 2021

peculiarity of the personality of a mentally retarded child is in close connection with the peculiarities of his activity, in which the personality is formed. These features are due not only to the low intellectual level of this category of children, but also to deviations in the structure and motivation of its activity. Much of what a normally developing child independently acquires in preschool age, the mentally retarded receives later and only in the process of special education. [3]

It has been established that mentally retarded primary schoolchildren are not always able to subordinate individual actions to the tasks assigned to them, they are not able to comprehend them completely and outline a general plan for implementation. There are violations of the purposefulness of activity, which are manifested in this category of children in the wrong orientation in the task, in the wrong planning of its implementation, in an inadequate attitude to the difficulties encountered and in the absence of criticality to the results obtained.

Many authors note that the motivational-need sphere occupies an essential place in the complex structure of the emerging personality of the child. However, this process in a mentally retarded child is carried out on a defective basis, under conditions of limited damage to the central nervous system that arose in the early, prespeech period of life. Disorders of the most important brain structures have a multifaceted effect on the child, in particular, they reduce his need for new impressions, thereby dramatically inhibiting social development [1].

Regarding the general characteristics of the motivational-needs sphere of mentally retarded children, there is a point of view that points to the uniqueness of personality development, in particular the structure and motives of the activities of these students. All authors note the immaturity of the motivational-needs sphere of students, their underdeveloped cognitive activity, weak manifestation and short duration of motives for activity, limited and unstable motives of activity, insufficient formation of social needs. The immaturity of the motivational sphere of mentally retarded schoolchildren is revealed in the fact that motives are formally assimilated by them, becoming their own motives and aspirations. As this category of children learns and develops, the motives of their activities become more differentiated, longlasting, and effective. The nature of the motivation of their actions changes and becomes more complicated.

The motives that motivate them have a great influence on the activity of mentally retarded schoolchildren. Data on the peculiar performance of the task by schoolchildren with intellectual disabilities testify to the peculiarities of the motivational sphere of these children. Depending on the nature of the tasks facing the students, they distinguish between distant and close motivation. The range of motivation has a significant impact on the nature of the actions performed, on the child's attitude to the difficulties encountered and the results obtained [2].

When performing just a variety of activities, mentally retarded students have a rapid depletion of impulses, the so-called "mental satiety." Along with this, the research of psychologists reflected a positive trend characterizing age-related changes in the motives of the activity of mentally retarded schoolchildren. Affectively colored, albeit insufficiently conscious, motives of activity can persist and be realized by schoolchildren for a rather long period [2].

Psychological studies give grounds to say that by school age, the motives of the learning activity of mentally retarded children turn out to be situational, very unstable and are formed 
CURRENT RESEARCH JOURNAL OF PEDAGOGICS 2(11): 138-142,

November 2021 DOI: https://doi.org/10.37547/pedagogics-crjp-02-11-26

ISSN 2767-3278

(C)2021 Master Journals

Crossref do: 81 Google

Accepted $25^{\text {th }}$ November, 2021 \& Published $30^{\text {th }}$ November, 2021

extremely slowly. The most common among elementary school students are indifferent and outwardly positive attitudes towards learning. Rarely are students with an active negative attitude towards learning activities [2].

At the same time, the emotionally colored attitude of a small mentally retarded schoolchild to a teacher expands the scope of motivation for his learning activity, contributes to the development of a positive attitude towards learning in general. Gradually, motivation becomes more difficult. Children begin to be guided by motives, which are based on an understanding of the usefulness of work and even social significance. If the leading motive for the student of the auxiliary school is the desire to achieve results, then many disadvantages of his activity are overcome, such as the tendency to "slip", i.e. change in the goal. Individual actions begin to more than usually correlate with the requirements of the task. Help given to adults becomes more effective as children need it. One of the possible ways to achieve success in activity is the organization of such conditions that provide the creation of a positive background for learning and enable the student to get satisfaction from this activity.

To achieve good results in teaching and upbringing of schoolchildren with intellectual disabilities, an organization of the pedagogical process is necessary that would encourage them to be guided in their actions not only by the motives associated with the need to fulfill the teacher's requirements, but also by the motives generated by their own needs and interests. No matter how low the level of general development of students with intellectual disabilities is, they have their own, albeit limited, needs and interests. When meeting these needs and interests, they show the necessary activity and an adequate attitude to the tasks facing them. And this is understandable: you cannot strive in your actions towards a certain goal and at the same time ignore it.

According to I.P. Ushakova, the peculiarity of the attitude to the learning activity of schoolchildren with intellectual disabilities is that it develops for the most part under the influence of external stimuli. The impact of internal motives in comparison with the norm is strongly limited, which is due to the peculiarity of the defect and mental development.

In the process of developing a positive attitude towards learning activity among students with intellectual disabilities, a number of qualitative personality changes occur: some of their character traits, inclinations, interests, activity, etc. change.

I.P. Ushakova notes that among a group of students who, by the end of a special school, had reached the highest level of attitude towards learning, the main motives of their educational activities were such as interest in the subjects studied and the desire to gain knowledge for mastering a future profession. They were quite conscious about the assimilation of school knowledge and school attendance.

At the same time, their views on future work began to correspond to the actual capabilities and abilities that they possessed. By the time they graduated from school, each of these students had a concrete idea of their future profession, thanks to which they strived to finish school as best as possible.

The interests of these students have significantly expanded and become more stable. They read a lot and borrowed from the library not only the literature recommended by the teacher. In addition, each of them studied in a circle, often on his own initiative, doing part of the circle work at home, and in the circle he helped younger comrades.

Collected later by I.P. Ushakova, follow-up data on the students of this group showed that their 
CURRENT RESEARCH JOURNAL OF PEDAGOGICS 2(11): 138-142,

November 2021 DOI: https://doi.org/10.37547/pedagogics-crjp-02-11-26

ISSN 2767-3278

(C)2021 Master Journals

Crossref do: 81 Google

Accepted 25th November, 2021 \& Published 30 ${ }^{\text {th }}$ November, 2021

conscious attitude to learning activity and the formed habit of conscientiously treating their work served as a prerequisite for the successful mastering of a specialty in production and a conscientious attitude towards their duties.

Thus, after graduating from the special school, graduates of the special school became fullfledged members of society and benefited it to the best of their ability.

It is quite natural that not all students can form a high-level attitude towards learning. But at the same time, all students show an increase in activity, initiative, expansion of interests, the development of self-criticism, etc.

Along with this I.P. Ushakova notes that the defect does not create special obstacles in the formation of a positive attitude at the level of diligence and diligence, but complicates the formation of an internally conditioned attitude, prompted by conscious socially significant motives. The deeper the defect, the more complex its structure, the lower the level of attitude towards learning activity. She points out that a student's performance is not always directly dependent on the level of his attitude to learning activities. There are students who have a positive attitude towards learning and school, but have rather low academic performance. True, their attitude to learning is not prompted by broad social motives, but mainly stimulated by the teacher, educator, parents. Very often this group includes students with a predominance of the inhibition process. This is probably due to a decrease in the functional and dynamic activity of the central nervous system, with volitional insufficiency and a decrease in working capacity.

\section{Conclusion}

Summing up all that has been said, we note that under certain conditions and with the use of appropriate ways of pedagogical influence, with the correct organization of the influence of external and internal factors, it is possible for a significant mass of students of a special school to educate an attitude to educational activity at a sufficiently high level. Moreover, for many of them it will be prompted by motives of wide social significance in a form accessible to them, and will be formed from the attitude to knowledge as such, from the attitude to the educational process as a process of educational activity. In the course of fostering such an attitude, it is necessary that, in accordance with the above structure of attitudes towards educational activity, the formation of motives includes the formation of both cognitive interests and the desire for active cognitive educational activity. Thus, schoolchildren with intellectual disabilities have a short, unstable motivation for learning activity.

A feature of the attitude to the learning activity of schoolchildren with intellectual disabilities is that it develops for the most part under the influence of external stimuli. The impact of internal motives in comparison with the norm is strongly limited, which is due to the peculiarity of the defect and mental development. Students with intellectual disabilities can have both positive and negative attitudes towards learning activities. In younger schoolchildren with intellectual disabilities, motives associated with stimulation from the teacher, educator prevail.

\section{REFERENCES}

1. Ilyin E.P. Motivation and motives. - SPb, 2002

2. Kulagina I.Yu. Developmental psychology: child development from birth to 17 years / Univ Ros. acad. Education 5th ed. - M., 1999

3. Mamaichuk I.I. Psychological assistance to children with developmental problems, St. 
CURRENT RESEARCH JOURNAL OF PEDAGOGICS 2(11): 138-142,

November 2021 DOI: https://doi.org/10.37547/pedagogics-crjp-02-11-26

ISSN 2767-3278

(C)2021 Master Journals

Crossref dof 81 Google

Accepted 25 ${ }^{\text {th }}$ November, 2021 \& Published 30 ${ }^{\text {th }}$ November, 2021

Petersburg, 2001

4. Dalibaevna, N. D. (2021). GENDER EQUALITY IS ONE OF THE REQUIREMENTS OF A DEVELOPED SOCIETY. CURRENT RESEARCH JOURNAL OF HISTORY (2767-472X), 2(06), 82-85.

5. Alcalde, C., Navarro, J. I., Marchena, E., \& Ruiz, G. (1998). Acquisition of basic concepts by children with intellectual disabilities using a computer-assisted learning approach. Psychological Reports, 82(3), 1051-1056.

6. DJURAEVA, N. (2021). ATTITUDE TO WOMEN IN UZBEKISTAN IN PUBLIC POLICY AND STRATEGY. Journal of Information and Computer Science, (1), 52-56.

7. Falcão, T. P., \& Price, S. (2012, June). Tangibles for students with intellectual disabilities. In Proceedings of the 11th International Conference on Interaction Design and Children (pp. 371-374).

8. Vinogradova, G. A., Akhmadieva, R. S., Konovalova, V. M., Spirina, E. V., Kalugina, O. A., Erdyneeva, K. G., ... \& Mashkin, N. A. (2018). Releasers as factor of student ecological focus formation. Ekoloji, 27(106), 1409-1415.

9. DJURAEVA, N. (2021). ATTITUDE TO WOMEN IN UZBEKISTAN IN PUBLIC POLICY AND STRATEGY. Journal of Information and Computer Science, (1), 52-56.

10. Yusupova, N. (2020). Features of the Learning Activities of Students with Intellectual Disabilities. International Journal of Progressive Sciences and Technologies, 19(2), 227-229. 